\title{
Differentiation of an adult neuron cell line increases susceptibility to rabies infection
}

\author{
Marlén Martínez-Gutierrez ${ }^{1,2}$, Gladys A. Barrera ${ }^{2}$, Samanda L. Aponte ${ }^{1,2}$, Johanna Baquero ${ }^{1}$, \\ Magda Y. Beltrán ${ }^{1}$, Esperanza Recio-Pinto ${ }^{3}$, Antonio C. Jaramillo ${ }^{2}$, Jaime E. Castellanos ${ }^{1,2}$ \\ ${ }^{1}$ Laboratorio de Neurociencias, Instituto Nacional de Salud, Bogotá, D.C., Colombia. \\ 2 Instituto de Virología, Universidad El Bosque, Bogotá, D.C., Colombia. \\ ${ }^{3}$ Anesthesiology Department, New York School of Medicine, New York, USA.
}

Una gran variedad de modelos in vitro se usan para estudiar la infección por virus de rabia, pero hasta el momento no se dispone de una línea neuronal adulta del sistema nervioso central (SNC) para dichos estudios. Por esta razón, nuestro objetivo fue determinar la susceptibilidad de una línea neuronal adulta del SNC (CAD-R1) a la infección por virus de rabia. Para ello, los cultivos se mantuvieron por 5 días en medio con suero (células CAD-R1 indiferenciadas) o sin suero (células CAD-R1 diferenciadas). Luego, se infectaron con una cepa de virus de rabia altamente neurotrópica (CVS) mantenida en células de tipo fibroblástico (CVS-BHK) o en cerebro de ratón (CVS-CR). Los dos tipos de células (indiferenciadas y diferenciadas) se infectaron con ambas cepas de virus de rabia; la proporción de células infectadas en los cultivos diferenciados fue mucho mayor (porcentajes de infección de 83,2\% y $78,7 \%$ para CVS-BHK y CVS-CR, respectivamente) que en las células indiferenciadas (51,4\% y $60,4 \%$ ) (prueba t de Student $<0,05$ ). Estos datos indican que la susceptibilidad a la infección es dependiente del estado de diferenciación celular, posiblemente debido a que estas células adquieren características morfológicas y bioquímicas durante el proceso de diferenciación, que las hace más susceptibles a la infección por el virus de rabia. Con estos resultados, se puede concluir que las células CAD R1 son un buen modelo de infección para el virus de rabia, lo que las convierte en una excelente herramienta para estudiar el neurotropismo del virus de rabia, la patogenia de la infección, el aislamiento de virus o la producción de vacunas más seguras y potentes.

Palabras clave: virus de rabia, cultivo celular, líneas neuronales, inmunocitoquímica

Diffrentiation of an adult neuron cell line increases susceptibility to rabies infection

A wide variety of in vitro models have been used for studying rabies infection, however, currently, no central nervous system (CNS) adult neuron cultures are available. The current study determined the susceptibility to rabies infection in an adult CNS neuron cell line (CAD-R1). Cultures of CAD-R1 cells were held for 5 days in medium containing serum (undifferentiated CAD-R1 cells) or in serum-free medium (differentiated CAD-R1 cells). They were then infected with highly neurotropic rabies virus (RV) strain (CVS), obtained from fibroblastic cells (CVS$\mathrm{BHK}$ ) or from adult mouse brain (CVS-MB). Undifferentiated and differentiated cells were infected with the two RV strains, but the percentage of infected cells in differentiated cultures was significantly greater ( $83 \%$ and $79 \%$, respectively) than in undifferentiated cells $(51 \%$ and $60 \%)$ (Student's t test<0.05). Susceptibility to infection apparently depended on cellular differentiation state, possibly due to acquisition of additional morphological and biochemical characteristics during the differentiation process that made them more susceptible to RV infection. Therefore, CAD R1 cells may represent a good model for RV infection, making them a useful tool for studying RV neurotropism, infection pathogeny, isolation of street virus or producing safer and most potent vaccines.

Key words: rabies virus, cell culture, neuronal cell line, Immunocytochemistry 
Rabies virus is a highly neurotropic virus, that infects mainly mammal central nervous system (CNS), producing lethal encephalitis (1). Marked neurotropism of rabies virus could be partly explained by the presence of molecules in the neuron membrane which could be acting as viral receptors (2). Recent rabies virus infection pathogeny studies have been mainly focused on the search for such molecules possibly explaining neurotropism and participating in promoting infection (3). Three proteins have been postulated as putative receptors for rabies virus to date: nicotinic acetylcholine receptor (NAChR) (4), neural cell adhesion molecule (NCAM) (5) and low affinity neurotrophin receptor (p75 NTR) (6).

A great variety of in vitro models for both CNS and peripheral nervous systems (PNS) have been used for studying rabies virus infection, including primary dorsal root ganglia cultures (7) or brain neurons $(8,9)$ and diverse cell lines $(10,6,11)$. The main disadvantage regarding primary cultures is non-neuronal cell presence, making it difficult to study the virus interaction with neurons and the need to supplement them with exogenous neurotrophic factors for neuron survival and maintenance, which could affect $R V$ replication (12). On the other hand, the most frequently used cell lines in virus experiments are non-neuronal and those which are neuronal are embryonic, behaving differently to adult neurons (13). There is currently no CNS adult neuron culture model available for studying $R V$ infection.

Rabies virus presents strict neurotropism in vivo, but it can also infect non-neuronal cells in vitro. It is well known that the fixed Challenge Virus Standard (CVS) rabies virus strain preferentially infects a certain type of cells depending on the type of cells in which they have been adapted $(13,14)$. If it has been maintained in adult mouse brain (CVS$\mathrm{MB}$ ) it becomes more pathogenic and neurotropic

\footnotetext{
Correspondencia:

Marlén Martínez, Instituto de Virología, Universidad EI Bosque, Transversal 9A No. 132-55, Laboratorio 205, Bogotá, D.C., Colombia.

Teléfono: (571) 633 1368, extensiones 209 y 272; fax: (571) 6252030.

martinezmarlen@unbosque.edu.co
}

Recibido: 24/04/03; aceptado: 31/01/04 than if it has been adapted to fibroblastic cells (CVS-BHK), in which case (in spite of continuing to be neurotropic) infecting a greater percentage of non-neuronal cells in primary cultures $(14,15)$.

A CNS neuron cell line (called CAD) has recently been isolated (16), this being a variant of the $\mathrm{CATH} \alpha$ catecolaminergic cell line (obtained by direct tumorogenesis in adult mouse locus coeruleus) (17). Both cell lines express biochemical neuron markers (synaptophisin 38 and neurofilament) and show neuronal physiological characteristics (voltage-dependent sodium and calcium currents) $(18,19)$. Additionally, CAD cells express other biochemical markers such as $\beta$-tubulin III, GAP-43 and sinaptotagmin 65 with stronger intensity $(16,20)$. The main characteristic of $\mathrm{CAD}$ is that it acquires neuronal morphological features when it is cultured in serum-free medium. CAD-R1 cells represent a subclone derived from CAD, characterized by $98 \%$ of the cells having rounded morphology and all cells becoming differentiated following culture in serum-free medium (19). It can be said that this neuronal cell line is the only one reported to date having adult neuron morphological, biochemical and physiological characteristics expressed on being cultured in serumfree medium.

In spite of vaccination against rabies having been developed a century ago, this disease continues to be considered zoonotic and mortal in many countries, its main reservoirs being wild animals (21). The search is thus being continued to find out more about the infection pathogeny, proposing improved models for isolating wild type virus and producing new, safer and more powerful vaccines than the existing ones (22). Bearing in mind that there is no CNS adult neuronal line currently available for studies into RV neurotropism (as a possible improved substrate for isolating the virus and its possible use in producing vaccines), the aim of this work was to determine the CAD-R1 susceptibility to rabies infection, in its two states of differentiation, by two variants of a fixed $\mathrm{RV}$ strain (CVS-BHK and CVS-MB).

\section{Materials and methods}

\section{$C A D-R 1$ cell cultures}

CAD cells were kindly provided by D. Chikaraishi 
and J. Wang. CAD R1 subclone was obtained by Recio-Pinto and coworkers (18) and cultured in DMEM/F-12 with $8 \%$ foetal bovine serum (FBS, Hyclone) (maintenance medium, MM), $100 \mathrm{U} / \mathrm{ml}$ penicillin and $0.1 \mathrm{mg} / \mathrm{ml}$ streptomycin also being added. They were kept in $25 \mathrm{~cm}^{2}$ culture flasks until reaching $80 \%$ confluence and then were subcultured and seeded in 24-well plastic dishes, on glass coverslips (treated with $10 \mu \mathrm{g} / \mathrm{ml}$ poly-Llysine) at 1,000 and 2,000 cells per well density for CAD-R1 undifferentiated and differentiated cells, respectively. The medium was changed for the first time 24 hours after cells were seeded; one part of the cells was kept undifferentiated using MM and the other part was differentiated by replacing MM with serum free differentiation medium (DM) and adding apotransferrin $(20 \mathrm{ng} / \mathrm{ml})$ and sodium selenite $(50 \mathrm{ng} / \mathrm{ml})$. The medium was changed each 48 hours up to the fifth day.

\section{Virus and culture infection}

Virus variants have already been described (14). CVS-11 adapted to mouse neonatal brain (donated to the Colombian NIH by PAHO/WHO) was used to produce two different virus strains: BHK-21 adapted CVS (CVS-BHK) and adult ICR mouse brain-adapted CVS (CVS-MB) at $10^{5.3}$ and $10^{7.2} \mathrm{LD}_{50}$ titres, respectively. The virus produced was titrated by calculating the $\mathrm{LD}_{50}$ (lethal dose 50 ) following intracerebral injections of increasing dilutions in young ICR mice (14-16). Viral dilutions were prepared in appropriated medium (MM or MD) from stocks of CVS-BHK and CVS-MB strain. CAD-R1 cells were infected for 1 hour on the fifth day of cell culture, washed and incubated for 24 hours at $37^{\circ} \mathrm{C}$ with fresh medium to allow viral replication.

\section{Immunocytochemistry for rabies virus}

Cultures were fixed on the sixth day with $4 \%$ paraformaldehyde. They were then permeabilized with $0.1 \%$ Triton $\mathrm{X}-100$ followed by endogenous peroxidase quenching $\left(0.5 \% \mathrm{H}_{2} \mathrm{O}_{2}\right.$ in $50 \%$ methanol) and blocking unspecific sites (PBS plus $10 \%$ neonatal calf serum, NCS). Primary antirabies virus antibody (BioRad 72114C, 1/1000 dilution) was prepared in 5\% NCS and incubated for 1 hour at $37^{\circ} \mathrm{C}$. Secondary biotinylated antirabbit IgG was similarly prepared in 5\% NCS and incubated at room temperature for 30 minutes, followed by Avidin-Biotinylated peroxidase complex (Vector Ltd.) for 30 minutes. Coverslips were revealed with $0.1 \% 3,3$ ' diaminobenzidine tetrahydrocloride in Tris- $\mathrm{HCl} \mathrm{pH} 7.2$ and $0.02 \%$ $\mathrm{H}_{2} \mathrm{O}_{2}$. They were later counterstained with Mayer's Hemalum and dehydrated with ascending alcohol concentrations and xylene. Coverslips were mounted with Permount ${ }^{\circledR}$. Mock infected cultures were processed as negative controls.

\section{Quantitative and statistical analysis}

Two cultures were done with 4 replications for each one $(n=8)$, for each type cell which was infected with the two strains of the virus. Between 3,000 and 10,000 total neurons were counted (infected and non-infected) in ten random fields to obtain infection proportions, later subjected to angular transformation, Student's t test was used for statistical analysis $(p<0.05)$ to compare undifferentiated and differentiated cells infected with each type of virus (CVS-BHK and CVS-MB).

\section{Results}

\section{Morphology of cultures in phase contrast microscopy}

Most undifferentiated cells had highly bright rounded soma; however, it is common to find some amorphous and opaque cells in culture (figure 1A). Differentiated cells were characterised by presenting neuritic prolongations which were twice the diameter of their soma (figure 1B). No apparent morphological differences were observed between infected and non-infected cultures.

\section{Immunocytochemistry}

The indirect peroxidase immunodetection technique showed immunoreactivity for rabies virus in vesicles located in the soma of both types of cells (figures 2A-B and 2D-E); intense staining in neuritic prolongations was also found in differentiated cells (figures 2D and E). Non-infected and processed cultures and those infected cultures to which no anti-rabies antibodies were added used as negative controls did not show reactivity (figures $2 \mathrm{C}$ and $\mathrm{F}$ ). Percentage of infected cells is apparently greater in differentiated cells than in undifferentiated ones with whichever of the two viral strains. 

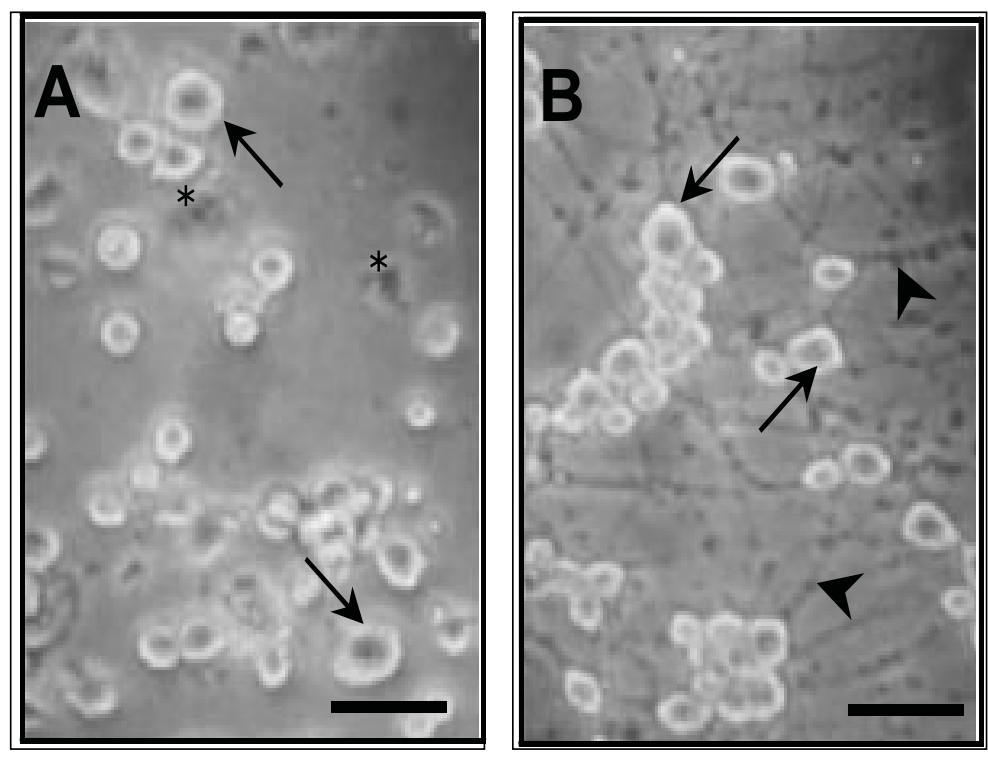

Figure 1. Phase contrast photomicrograph of live cells: undifferentiated CAD R1 cells in maintenance medium ( $8 \%$ FBS) (A) or differentiation medium (serum-free medium plus apotransferrin and sodium selenite) (B). Brigth rounded soma can be observed in both cases (arrows). In the case of the undifferentiated cells, some amorphous and opaque cells can be seen (asterisk). Neuritic prolongations can be seen in differentiated cells (arrowhead). Bar: $50 \mu \mathrm{m}$.

\section{Infection percentages}

Comparing infection with the two variants of virus used (CVS-BHK or CVS-MB) in undifferentiated and differentiated CAD-R1 cell cultures, it was found that the infection percentages were significantly greater in differentiated cells than in the undifferentiated ones for both viruses $(p<0.05)$. Infection percentages with CVS-BHK were $83.2 \%$ in differentiated cells and $51.4 \%$ in undifferentiated cells (figure $3 \mathrm{~A}$ ). The same happened with CVSMB infection, as the percentage of infected differentiated cells was $78.7 \%$ and that for undifferentiated cells was $60.6 \%$ (figure 3B). No significant differences were found on comparing infection percentages produced by the same viral strain in differentiated or undifferentiated cells.

\section{Discussion}

When CAD-R1 cells were cultured in MM (with FBS) they continued to proliferate; more than $95 \%$ of the population had rounded and bright morphology, however, some amorphous and opaque cells were also found as previously (19). Twenty four hours after being changed to MD (serum-free medium), cells lessened their proliferation and began to acquire a differentiated phenotype, reaching their greatest degree of differentiation after 96 hours. Such differentiation was reversible as adding FBS induces neurite retraction and prolifera- tion begins again. The fact that CAD-R 1 cells could stay alive in serum-free medium was due to their ability to produce autocrine or paracrine neurotrophin-3 (20).

It has been considered that these cells become completely differentiated (morphological, biochemical and physiologically) 96 hours after being cultured in serum-free medium (16); infection was thus begun on the fifth day after beginning the culture. No morphological damage or cytolytic effect was observed in cells 24 hours post-infection with CVS rabies virus strain, agreeing with previous data in which it has been proposed that highly neurotropic strains do not cause neuron death (13).

Comparing the percentages of undifferentiated and differentiated cells infected with each one of the viral strains, it was found that both strains infected a greater percentage of differentiated cells $(p<0.05)$, ratifying their in vitro neurotropism. This greater percentage of infection in differentiated cell cultures is possibly because differentiated CAD-R 1 cells acquire morphological and biochemical characteristics which they do not possess in their undifferentiated state (16). Moreover the cell differentiation could change enzymatic machinery involved in viral replication. Preliminary results from our group indicate that the three molecules postulated as rabies virus receptors ( $p 75^{\mathrm{NTR}}$, 

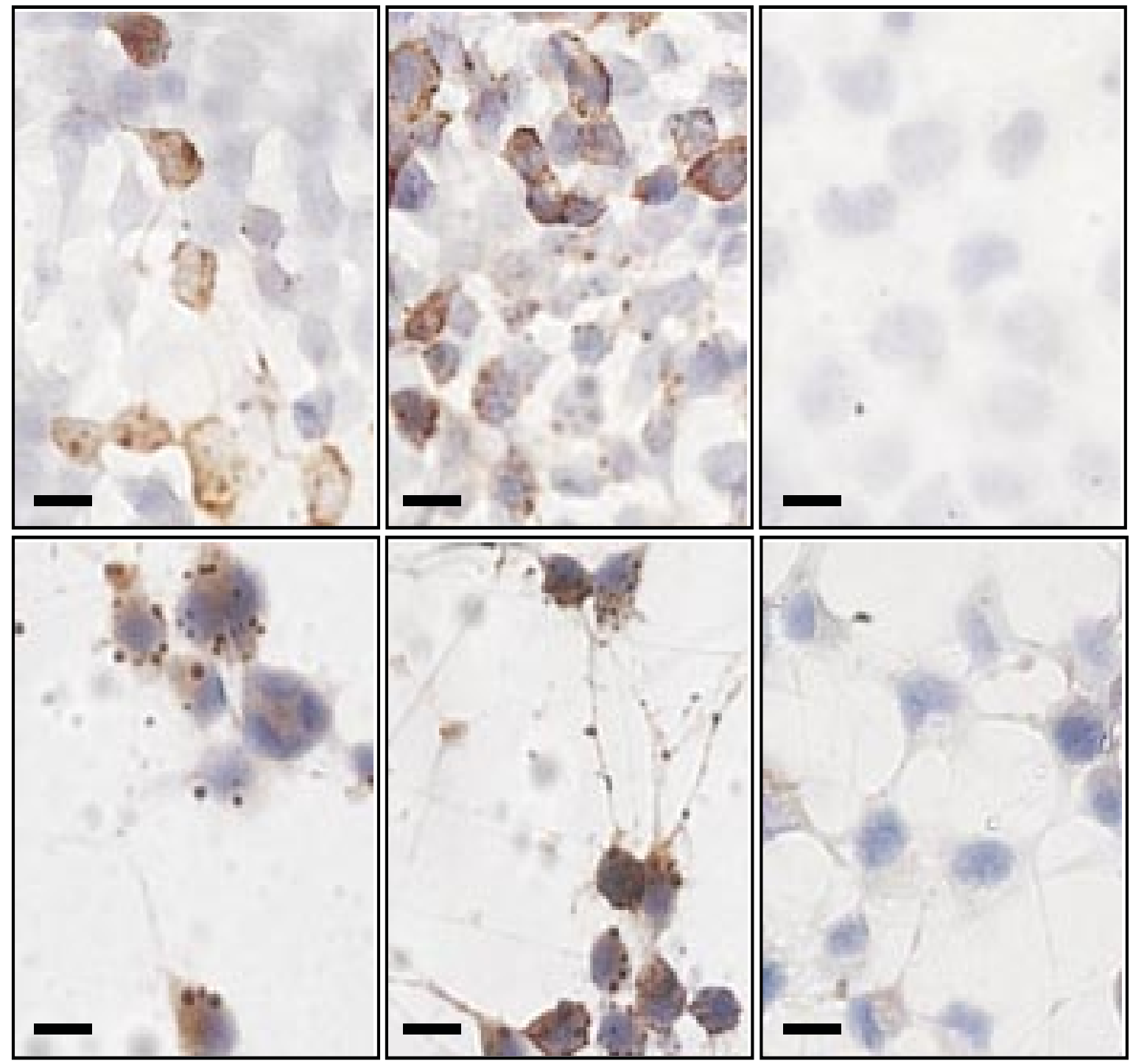

Figure 2. Indirect immunoperoxidase for rabies virus in undifferentiated $(\mathbf{A}, \mathbf{B}$ and $\mathbf{C})$ and differentiated (D, E and $\mathbf{F})$ CADR1 cells. A and D: infection with CVS-BHK rabies virus strain; $\mathbf{B}$ and $\mathbf{E}$ : infection with CVS-MB strain. $\mathbf{C}$ and $\mathbf{F}$ : mock infected cultures processed as negative control. Bar: $20 \mu \mathrm{m}$.

NCAM and NAChR) are found on CAD-R1 cells, but cell number and staining intensity is greater in differentiated cells (23). In spite of it being known that the rabies virus CVS strain acquires different genotypical and phenotypical characteristics, depending on substrate in which it is maintained $(13,14)$, no infection differences between CVS-BHK and CVS-MB strains were found in the present study.
Even though vaccination against rabies was developed more than a century ago, the disease continues to be considered as being a public health problem in underdeveloped countries $(21,22)$. Control of rabies is based on several activities including animal massive vaccination, development of more potent and safer vaccines (24), establishing more sensitive and economic diagnostic techniques (25) and studying new drugs 


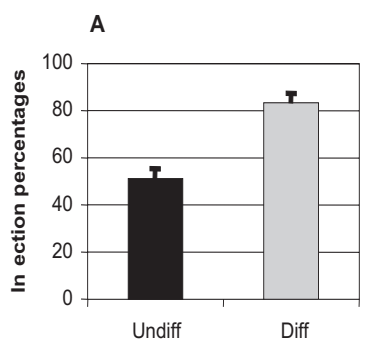

B

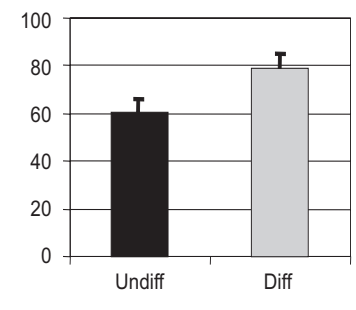

CAD-R1 cells

Figure 3. Infection percentages of undifferentiated (undiff) or differentiated (diff) CAD-R1 cells with rabies virus CVSBHK (A) and CVS-MB (B) strain. Two cultures were done with 4 replications for each one $(n=8)$, for each type cell which was infected with the two strains of the virus. Infection proportions were subjected to angular transformation and subsequently analyzed by Student's t test. This analysis revealed that infection for the two types of virus were significantly greater in differentiated cells $(p<0.05)$.

allowing the infection to be treated once it reaches CNS (26). Neuronal cell lines (such as CAD-R1) having high susceptibility to infection by rabies virus will thus facilitate viral cycle basic research and how to interrupt it, as they can be used as substrate for virus isolation (replacing the mouse inoculation test) or to test experimental sera or drugs.

If these cells are also considered for producing vaccines, the fact of being able to culture them in serum-free medium favours cost and avoids biological safety problems associated with use of cell lines cultured with FBS (27). We are thus dealing with a biological model having ideal characteristics, as culture conditions and cell susceptibility to infection can be controlled, opening infinite possibilities for practical use of this cell line.

\section{Conclusion}

CAD-R1 cells are susceptible to being infected by rabies virus; both differentiated and undifferentiated cells were infected in percentages greater than $50 \%$. Differentiation state affected infection percentage, as differentiated cells became infected in greater percentages than undifferentiated ones, possibly indicating biochemical changes favouring virus adsorption or replication. The characterization of this cell line will allow their future use in basic research regarding virus-neuron interaction, testing new antiviral agents and even their use as substrate for producing safer virus vaccine.

\section{Acknowledgements}

The authors thank to Dona Chikaraishi and James Wang for kindly providing the CAD cells used in this study.

\section{References}

1. Rupprecht C, Hanlon CA, Hemachudha T. Rabies re-examined. Lancet Infect Dis 2002;2:327-43.

2. Castellanos JE, Hurtado H. Receptores para virus de rabia. Biomédica 2001;21:389-401.

3. Schweighardt B, Atwood WJ. Virus receptors in the human central nervous system. J Neurovirol 2001;7: 187-95.

4. Lentz TL, Burrage TG, Smith AL, Crick J, Tignor GH. Is the acetylcholine receptor a rabies virus receptor? Science 1982;215:182-4.

5. Thoulouze MI, Lafage M, Schachner M, Hartmann $\mathbf{U}$, Cremer $\mathbf{H}$, Lafon $\mathbf{M}$. The neural cell adhesion molecule is a receptor for rabies virus. J Virol 1998;72: 7181-90.

6. Tuffereau C, Benejean J, Blondel D, Kieffer B, Flammand $\mathbf{A}$. Low-affinity nerve growth factor receptor $\left(p 75^{\text {NTR }}\right)$ can serve as a receptor for rabies virus. EMBO J 1998;17:7250-9.

7. Castellanos JE, Hurtado H, Arias J, Velandia A. Rabies virus infection of cultured adult mouse dorsal root ganglion neurons. Mem Inst Oswaldo Cruz 1996;91: 621-5.

8. Ray NB, Power C, Lynch WP, Ewalt LC, Lodmell DL. Rabies viruses infect primary cultures of murine, feline, and human microglia and astrocytes. Arch Virol 1997;142:1011-9.

9. Guigoni C, Coulon P. Rabies virus is not cytolytic for rat spinal motoneurons in vitro. J Neurovirol 2002;8:30617.

10. Nogueira YL. Morphometric analysis of McCoy cells inoculated with cerebrospinal fluid from patients with rabies. Mem Inst Oswaldo Cruz 1998;93:509-14.

11. Kissi B, Badrane H, Audry L, Lavenu A, Tordo N, Brahimi M, Bourhy. Dynamics of rabies virus quasispecies during serial passages in heterologous hosts. J Gen Virol 1999;80:2041-50.

12. Castellanos JE, Martínez M, Acosta O, Hurtado H. Nerve growth factor and neurotrophin-3 modulate the rabies virus infection of adult sensory neurons in primary cultures. Brain Res 2000;871:120-6.

13. Morimoto K, Hooper C, Carbaugh H, Fang-Fu Z, Koprowski H, Dietzchold B. Rabies virus 
quasispecies: implications for pathogenesis. Proc Natl Acad Sci USA 1998;95:3152-6.

14. Castañeda-Castellanos D, Castellanos JE, Hurtado H. Differential use of the nicotinic receptor by rabies virus upon substrate origin. J Neurovirol 2002;8:150-4

15. Martínez M, Ramírez R, Hurtado H, Cepeda E, Avellaneda M, Benito M, Castellanos JE. Effect of nicotinic agonist chronic exposure on adult mouse normal and rabies virus infected spinal ganglia culture. J Neurovirol 2002;8(S1):109-10.

16. Qi Y, Wang JK, McMillian M, Chikaraishi DM. Characterization of a CNS cell line, CAD, in which morphological differentiation is initiated by serum deprivation. J Neurosci 1997;17:1217-25.

17. Suri C, Fung BP, Tischler AS, Chikaraishi DM. Catecholaminergic cell lines from an adrenal glands of tyrosine hydroxilase SV40 T antigenic mice. J Neurosci 1993;13:1280-91.

18. Lazaroff M, Dunlap K, Chikaraishi DM. A CNS catecholaminergic cell line expresses voltage-gated currents. J Membr Biol 1996;151:279-91.

19. Castañeda-Castellanos DR, Cano M, Wang JA, Cornbett A, Benson DD, Blanck T, Thornhill B, Recio-Pinto E. CNS voltage-dependent $\mathrm{Na}^{+}$channel expression and distribution in an undifferentiated and differentiated CNS cell line. Brain Res 2000;866:281-5.

20. Horton CD, Qi Y, Chikaraishi D, Wang JK. Neurotrophin-3 mediates the autocrine survival of the catecholaminergic CAD CNS neuronal cell line. J Neurochem 2001;76:201-9.

21. Hemachudha T, Laothamatas J, Rupprecht C. Human rabies: a disease of complex neuropathogenetic mechanisms and diagnostic challenges. Lancet Neurol 2002;1:101-9.

22. World Health Organization. Recommendations on rabies post-exposure treatment and the correct technique of intradermal immunization against rabies. URL: http://www.who.int/emc-documents/rabies/docs/ whoemczoo966.pdf; 2002.

23. Martínez-Gutiérrez M, Aponte S, Recio-Pinto E, Castellanos J. Neurotrophin inhibition of rabies virus infection in a central system neuron line (CAD-R1). J Neurovirol 2003;9-S3:124.

24. Dietzschold B, Schnell M. New approaches to the development of live attenuated rabies vaccines. Hybrid Hybridomics 2002;21:129-34.

25. World Health Organization. World survey for rabies No.35 for the year 1999. WHO/CDS/CSR/EPH/2002. Geneva: World Health Organization; 2002.

26. Jackson AC, Warrel MJ, Rupprecht C, Ertl HC, Dietzchold B, O'Reilly M, Leach RP, Fu Z, Wunner W, Bleck TP, Wilde H. Management of rabies in humans. Clin Infect Dis 2003;36:60-3.

27. Kallel H, Jouini A, Majoul S, Rourou S. Evaluation of various serum and animal protein free media for the production of a veterinary rabies vaccine in BHK-21 cells. J Biotechnol 2002;95:195-204. 